Zagadnienia Rodzajów Literackich, LXI, z. 1

PL ISSN 0084-4446

DOI: https://doi.org/10.26485/ZRL/2018/61.1/1

Urszula Terentowicz-Fotyga

Uniwersytet Marii Curie-Skłodowskiej*

\title{
When the Mind Becomes a Place: The Modernist Psychological Novel
}

\begin{abstract}
The paper focuses on the modernist psychological novel as a genre that dramatizes the radical transformations of spatial and temporal categories of the time. The genre is often identified with the narrative experiments of stream of consciousness, which represent the mind in and through time. Yet an equally important inheritance of the generic experiments is the spatialization of the mind - understood in the context of the spatial conception of human subjectivity and in terms of the spatial character of inner reality. The paper argues that the most vivid spatialization of the mind is evident in the portrayal of schizophrenic experience and demonstrates the thesis in the analyses of two novels - Virginia Woolf's The Waves and Samuel Beckett's Murphy.
\end{abstract}


* Instytut Anglistyki, Uniwersytet Marii Curie-Skłodowskiej Pl. M. Curie-Skłodowskiej 5, 20-031 Lublin e-mail: uterentowicz@hektor.umcs.lublin.pl 
Among the transformations that most significantly shaped the first decades of the twentieth century were those involving space and time. The modernist paradigm entailed a marked change in the self's experience of the world and a radical redefinition of the scientific, philosophical and artistic conceptualizations of the spatio-temporal dimension. New technological developments, means of transport and communication redefined the daily experience and constructed new spatialities and temporalities. The Newtonian world-view, entailing the existence of absolute, objective, homogenous space and time, had already been seriously problematized by Kant's epistemology, which envisioned time and space as forms of experience and understanding determined by the observer even if still aspiring to universality. But it is only the broad intellectual impact of the theory of relativity formulated by Albert Einstein and perspectivism, developed by Friedrich Nietzsche and José Ortega y Gasset that truly captured the modernist imagination. The two theories, whose near-simultaneous publication Ortega himself considered a sign of the time, "signified a breakdown of the old notion that there is a single reality in a single, absolute space" (Kern 1983: 151). Both denied the existence of universal categories independent of the position of the individual observer. "With the general theory of relativity the number of spaces increased beyond calculation to equal the number of moving reference systems of all the gravitational fields generated by all of the matter in the universe" (Kern 1983: 136). Perspectivism proclaimed that there are as many realities as there are points of view; it argued that there are no universal facts and truths, only observations and interpretations. Perspective thus becomes a component of reality and since there is no absolute perspective, there is no absolute space and time.

As a result of the modernist loss of a stable external reality, "space and time occupied a peculiar position in the imagination of the 1920s, provided (...) a fashionable terminology particular to the decade" (Stevenson 1992: 10). Rather than being transparent containers of action, they became "forms of thought — ways of thinking" (Stevenson: 227), as May Sinclair wrote in her 1919 novel Mary Olivier. The new "forms of thought" forged new relations between the self and the world, new ways of experiencing one's being in the world. Once the perspective is reality, the individual mind becomes the centre of meaning. 
Space and time as new "forms of thought — ways of thinking" shaped not only novel ways of looking at the relationship between the self and the world but also new forms of artistic expression. Spatiality and temporality became central categories that defined the themes and forms of modernist art. One way of looking at the experiments of the era is to see them in the context of Gotthold Lessing's taxonomy that divided art forms into spatial and temporal. In modernism the visual arts, traditionally considered spatial, tried to introduce time into their form, while those that are naturally temporal, based on narrative progression, aimed at overcoming linearity. Thus, as Stephen Kern explains, the Impressionists' sequences of landscapes portraying the same view at different times of day and seasons, Cubists' multiple perspectives inscribed on a single canvas, and Giacomo Balla's dynamic paintings all involved introducing time into an essentially spatial artistic form (Kern 1983: 21-2, 84). By contrast, the spatial form in literature, focusing on the frozen and/or epiphanic moment and constructing a complex architectonics of interpretation, aimed at overcoming the linearity of narrative (Frank 1991).

The importance of space and time as "forms of thought" had a big impact on the development of the modernist psychological novel. The genre came into existence together with and as a result of the inward turn (Edel 1964: 11) and its appearance had as much to do with the development of psychology as a new discipline and the broad impact of Freudian psychoanalysis on the way the human self is conceptualized as with the new sense of time and space. If the perspective is reality; if, as May Sinclair writes, "all that is perceived in space or time, and with it all objects (...) have no existence grounded in themselves outside our thoughts" (Sinclair 1982: 247) then reality is in the mind. The question that follows is how one represents the inner self and the mental experience of constructing the world. How can language record "an incessant shower of innumerable atoms; and as they fall, as they shape themselves into the life of Monday or Tuesday" (Woolf 1925: 150 ) and how can the narrative convey the process? "Since the self [as Bergson insisted] is an endless change of sensibility, the authentic selfhood can only be lived, not thought; our real existence must be sought in the shifting currents of our most immediate consciousness" (Sypher 1962: 59) that discursive language has problems capturing and expressing.

The different ways modernist artists responded to the problem of representing the mind had much to do with the new forms and theories of space and time. The genre of the modernist psychological novel is often identified with the narrative experiments of stream of consciousness or interior monologue, with James Joyce's Ulysses, Marcel Proust's Remembrance of Things Past and Dorothy Richardson's Pilgrimage. These works are often called "time-novels" not only because "time might be said to be their primary concern" (Edel 1964: 94) but also because they represent the mind as and in time. They use narrative progression - even if no longer logical, discursive or chronological — "to create the illusion of a mind flowing with thought and image and impression" (Edel 1964: 125); they conceive reality as a process developing in time.

Yet if in modernism time is an important way of thinking about the inner experience and the mind's construction of reality, so is space. The idea of the spatial character of the mind, as I shall argue in more depth, is an equally important development and inheritance of the modernist psychological novel. In modernist writing, the mind is conceived of as a flow of thoughts but it is also envisaged as a place, a spatially imagined world of its own. The spatial character of the mind needs to be understood in two ways: firstly, in terms of 
the spatial conception of human subjectivity, whereby the mind and the human self are conceptualized in spatial terms; and secondly, in terms of the spatial character of inner reality, made all the more real, as I have explained and will demonstrate in more detail, by the modernist inward turn and the crisis of external coordinates of experience, or in other words by the ontological redefinition of the relationship between inner and outer worlds.

The spatial conception of human subjectivity is rooted in a more general tendency to describe human subjects and their relations with the world in spatial language, entailed in the Cartesian division into res extensa - the realm of matter — and res cogitans, the world inside. The Cartesian assumption "that the self can be imagined as a kind of physical space inside of which one's thoughts move about" (Sass 1992: 370) is an integral part of the process of interiorization and spatialization of the mind in Western culture. Yet, for modernism it is the Freudian topologies of the mind that were of crucial importance, as "they conceptualize the psyche as a spatial entity, and at the same time present it as a constellation of several systems or »mental localities «" (Keitel 1989: 29). As Nicholas Dion in Spacing Freud: Space and Place in Psychoanalytic Theory (Dion 2012) explains, Freud's models of the mind are called topographies in so far as they depict the human psyche and the self's relation to the world in terms of a spatial layout. The different agencies of the mind - the unconscious and conscious in the first topography and the id, ego and superego in the second — stand in a regular spatial relation to one another: "If the ego emerges as a defined space within the id, the superego forms such a space within the ego" (Dion 2012: 95). The three are often described as "realms [Reiche], regions [Gebiete], provinces [Provinzen], into which we divide an individual's mental apparatus" (Dion 2012: 97). In Freud, "[t]he creation of the subject, then, can be understood psychoanalytically as a partitioning of space" (Dion 2012: 23) and a definition of reality arises "through a spatial process, the creation of a boundary between inside (subject) and outside (object)" (Dion 2012: 64). While spatial language in Freud is used metaphorically and mental spaces should not be considered concomitant with the physiological division of the human brain, it nevertheless offers an important conceptual and visual paradigm that orients and organizes thinking about the human self and the relationship between inner and outer realities. Conceptualizing the mind as a place not only offers a tangible, embodied way of thinking about the abstractions of the psyche but also paves the way for the more radical remodelling of the inner realm that comes with an ontological redefinition of the relationship between inner and outer realities.

The metaphorization of human subjectivity in spatial terms is closely related to the process of spatialization of inner reality. "Being in the mind" means "being in and through" one's flow of thoughts but it is also represented as being in a different realm, in a separate space of inner experience. The concept of inner space has a deeply metaphorical meaning and yet with the crisis of external coordinates of experience and the increasingly problematic sense of reality, the sharp ontologies separating the realm of phenomena from the realm of the psyche become increasingly blurred. In modernist works the external, phenomenal world is often "derealized, robbed of its substantiality or objectivity, its ontological status as an entity or horizon independent of the perceiving subject" (Sass 1992: 32). The emphasis can be put "on the loss of the feeling that reality is external or on the loss of reality's aura of significance" (Sass 1992: 32), the two processes being often closely related. Once the outer world is derealized, the inner one becomes more real and 
in effect it is often imagined in cosmological terms, as a separate universe, conceived as a spatially developed realm.

The most radical spatialization of the inner realm is connected with the most radical redefinition of the inner/outer ontologies and can be observed in the representations of schizophrenic and schizoid experiences. Louis A. Sass in the magisterial study Madness and Modernism: Insanity in the Light of Modern Art, Literature and Thought explores the relation between schizophrenia, "the quintessential form of madness in our time" (Sass 1992: 13), and modernist art, literature, and thought. He points to the similarities between schizophrenic experience and modern literary forms. Both, he argues, are characterised by "derealisation, dehumanization (disappearance of the active self), giddy perspectivism or relativism, and detachment" (Sass 1992: 318) and both manifest an off-putting "quality of being hard to understand or feel one's way into" (Sass 1992: 8). In contrast with the customary understanding of madness, which associates insanity with Dionizian frenzy, loss of control and animal instincts, schizophrenia is a form of acute hyperreflexivity; it results from too much thinking rather than too little. Schizophrenic experience, argues Sass:

may have less in common with the spirit of Dionysus than with what Nietzsche, in The Birth of Tragedy, associates with the god Apollo and the philosopher Socrates: it may be characterized less by fusion, spontaneity, and the liberation of desire than by separation, restraint, and an exaggerated cerebralism and propensity for introspection. (Sass 1992: 10)

Such a vision of madness resonates with changing patterns in the development of sensibility in modernist genres, emphasizing extreme self consciousness and proposing a new character type, a "psychological man" bent on his inner self rather than on outer reality. Sass points to the close affinity between schizophrenia and the structure of consciousness found in modernist literature: both are characterized by acute self consciousness, self-reference, and alienation from action, qualities he calls hyperreflexivity. Characters are represented as being and thinking rather than doing; withdrawing from active life in the way the protagonist in Thomas Mann's The Magic Mountain does. Modernist literature "radically probed the nature of selfhood and problematized the means whereby self could be expressed" (Brown 1989: 1). If the inner self became the focus of attention and the principal arbiter of reality, it was the self that was radically, often chronically divided and fragmented. The modernist dissolution of the self entailed a highly deconstructive vision of identity; rather than as "autonomous, integral and continuous" it was conceived as "pluralist, heterogeneous and discontinuous" (Brown 1989: 20-21). Modernist writers concentrated on the complex, intangible character of the self and emphasized a strong division between the body and the mind.

Schizophrenia can be seen as the most extreme form of the inward turn, the experience of the most complete withdrawal from the external world. The ontological relationship between inner and outer realities is radically redefined; the external, phenomenal world is derealized, deprived of sense and significance, while the inner one becomes the true source of meaning and order. What is significant from the perspective of the present considerations is the fact that a redefinition of the ontological status of reality entails a significant reconstitution of spatial and temporal coordinates. As Sass explains, schizophrenic experience may involve 
the most profound alterations in the very structures of human consciousness, in the forms of time or of space, causality, and human identity that normally provide a kind of bedrock foundation for a stable human existence. The sense of time or of space may be destabilized or radically transformed, the objective world may loom forth as a solid but strangely alien presence, or else may fade into unreality, or even seem to collapse or disappear. (Sass 1992: 14)

In effect, the inner world comes to be experienced and conceived of as a place, a spatially imagined realm of being, as real or even more real that the outer world. As the narrator in The Autobiography of a Schizophrenic Girl explains, this form of madness does not "feel like" a condition but "rather a country opposed to Reality, (...) an immense space without boundary, limitless, flat” (qtd. in Sass 1992: 47).

While the modernist representations of the mind in terms of the temporal flow have been well analysed (see e.g. Cohn, Humphrey, Quinones), the different forms of spatialization of the mind in the early psychological novel need to be examined in more depth. The paper will focus on two modernist novels in which the spatialization of the human mind is most evident. Virginia Woolf in The Waves and Samuel Beckett in Murphy portray radically divided, disembodied selves characteristic of the condition of schizophrenia. Though both writers use spatial imagery to represent the human mind and both portray the inner self as a place, they do so in very different ways. Woolf uses poetic language to present the inner mind in terms of symbolic landscapes, Beckett's approach is more discursive and theoretical. Considered together, the two novels represent well the contrasting approaches to the modernist spatialization of the mind that shaped the development of the psychological novel.

\section{Virginia Woolf's The Waves}

Virginia Woolf was among the key proponents of new type of fiction that aimed at representing the complexities of modern experience and new forms of subjectivity by means of the inward turn. In her quarrel with her predecessors, the materialists, as she called them, she criticised the fact that they represent characters through a meaningless accumulation of external detail:

if we speak of quarrelling with Mr Wells, Mr Bennett, and Mr Galsworthy, it is partly that by the mere fact of their existence in the flesh (...) It is because they are concerned not with the spirit but with the body $(. .$.$) they spend immense skill and immense industry making the trivial$ and the transitory appear the true and enduring. (Woolf 1925: 146-148)

While the body stands here as a metaphor of the material and the external, the phrase can also be read quite literally, as a reference to bodily rather than mental experience. At the centre of Woolf's artistic universe there is always the experiencing self, the mind constructing a vision and version of reality.

Virginia Woolf's interiorization of perspective found its fullest and we might say most extreme realization in The Waves, most specifically in the character of Rhoda, who might be considered the "most interior" of Woolf's protagonists ${ }^{1}$. While the novel in all its aspects — including the compositional clash of the interludes and the chapters and the

1 For an extended discussion of Woolf's spatiality, see Terentowicz-Fotyga 2006. For the analysis of different semiospheres in The Waves, see Terentowicz 1995; 1996. 
limited factual characterization contrasted with the scrupulous portrayal of minute flickerings of the mind - documents the breach between inner and outer realities, Rhoda represents the clearest separation of the body and the brain, of inner and outer realms.

From the opening images Rhoda speaks of herself as being different from other people. Though all the main characters in the novel define reality through personal images and phrases, Rhoda's "being in the world" is conveyed in highly idiosyncratic and distinct imagery that strongly evokes the sense of loss and alienation. In her soliloquies Rhoda emphasizes her profound sense of being estranged and ostracized and other characters describe her in similar terms, as somebody isolated from everyday life, incapable of communicating feelings or sharing thoughts. For Louis she "has no body as the others have" (Woolf 1992: 16); Bernard imagines her as "the nymph of the fountain always wet, obsessed with visions, dreaming" (Woolf 1992: 229). While other characters order the chaotic flux of life by imposing their individual structures and systems - Bernard language, Louis tradition, Neville philosophy, Susan maternity and Jinny sensuality — Rhoda is incapable of creating any permanently secure and orderly place in external reality. She compares life to an "emerging monster to whom we are attached" (Woolf 1992: 51) like "bodies to wild horses" (Woolf 1992: 50).

It is only when Rhoda is alone that she can feel secure to freely "replenish her dreams" (Woolf 1992: 99), to create the world of beauty and order in her imagination. In the evening, when going to sleep, feeling free from the pressures of the shared, external world and other people, Rhoda regains her composure and lives more fully:

'As I fold up my frock and my chemise,' said Rhoda, 'so I put off my hopeless desire to be Susan, to be Jinny. (...) Now I spread my body on this frail mattress and hang suspended. I am above the earth now. I am no longer upright, to be knocked against and damaged. All is soft, and bending. Walls and cupboards whiten and bend their yellow squares on top of which a pale glass gleams. Out of me now my mind can pour. I can think of my Armadas sailing on the high waves. I am relieved of hard contacts and collisions. I sail on alone under the white cliffs. (...) Travelling through darkness I see the stretched flower-beds, and Mrs Constable runs from behind the corner of the pampas-grass to say my aunt has come to fetch me in a carriage. I mount; I escape; I rise on spring-heeled boots over the tree-tops.' (Woolf 1992: 20)

As this quote suggests, being in the mind is presented as being in a different space. When Rhoda goes to bed, the material world gradually loses its substantiality and the inner one becomes more significant. The reality she constructs in her mind appears to her just as real or even more real than the outer, material world. The inner realm is conceived of as a landscape, withdrawing into the mental sphere is shown as moving in space. "Suspended" in the material world, Rhoda can travel freely into the realm of her dreams, a fully developed world of its own. The metaphor of spatial movement into the inner realm appears also in the soliloquies of other characters in reference to Rhoda. Observing her at the maths lesson, lost and baffled by the figures, Louis describes her escape from the reality of the here-and-now in spatial terms: "as she stares at the chalk figures, her mind lodges in those white circles, it steps through those white loops into emptiness, alone" (Woolf 1992: 16). Bernard ("Rhoda leave[s] us, flying past us to the desert"; Woolf 1992: 222) and Neville ("Rhoda flies with her neck outstretched and blind fanatic eyes, past us"; Woolf 1992: 164) refer to her moments of alienation similarly. 
Rhoda's divided self exists concurrently in two realities, which are presented as two separate spaces. The material, shared world that she sees as dangerous and threatening is contrasted with the safe inner reality of dreams and visions. Particularly revealing in this respect is Rhoda's soliloquy in the eighth interlude, in which all the characters gather at Hampton Court. In this passage the separation of the two worlds is signalled topographically by means of the brackets:

Behind you is a white crescent of foam, and fishermen on the verge of the world are drawing in nets and casting them. A wind ruffles the topmost leaves of primeval trees. (Yet here we sit at Hampton Court.) Parrots shrieking break the intense stillness of the jungle. (Here the trams start.) The swallow dips her wings in midnight pools. (Here we talk.) That is the circumference that I try to grasp as we sit together. (Woolf 1992: 186)

Rhoda's sense of self is split into two realities: the world of the present moment, which she shares with her friends, and the imaginary landscape "on the verge of the world" into which she escapes from the pressures of communal living. Particularly revealing here is the fact that it is not the world of the imagination but the reality of the here-and-now that is bracketed and in effect portrayed as less significant. From the perspective of the character, it is not the material world but the world of imagination, the imaginary exotic landscapes that she visits in her mind, that seem more real and more important. The duality of her being, described as a spatial separation of the inner and outer worlds is, Rhoda says, the "circumference" that she tries to understand and harmonize.

Rhoda is a dynamic character and the evolution she undergoes has much to do with the changing relations between inner and outer realities. While for other characters growing up means gradual adapting to the rules of the shared world, for Rhoda it means a more and more complete withdrawal from outer reality into the sphere of the mind. The immersion in the inner world depends on and results from a redefinition of the ontological status of both worlds, a gradual derealisation of the material, shared existence and an ontological realisation of the inner realm.

At the beginning of the novel the imaginary spaces are shown as fragile and insubstantial. They offer only a temporary refuge and a momentary escape. At this stage, Rhoda's imaginary reality seems to her but a "thin dream" easily "blow[n] to atoms" by the solidity of external reality (Woolf 1992: 44). She feels she cannot withdraw altogether from outer reality. She cannot disregard the external world as it is equipped with the authority of the whole of society, since for other people it is the only reality. Initially, Rhoda perceives the external world as real, solid, and substantial as opposed to her space, which is only a product of the imagination, an unreal, fragile, and temporary vision. The moments when she withdraws into the space of the mind and feels separated from the body are seen as perilous and threatening. She is afraid that unless she touches something hard and makes the effort to call herself back to the body she will "fall off the edge of the world into nothingness" (Woolf 1992: 33).

The most important moment in terms of the novel's plot, the death of Percival, marks the moment of Rhoda's epiphany. Percival's death makes her look closely at outer reality without transforming it into visions or dreams. In this moment of revelation almost every aspect of external reality is questioned: civilization, art, nature, friendship. The outer world suddenly appears much more insubstantial than it seemed to be; the houses prove 
so lightly founded that they can "be puffed over by a breath of air" (Woolf 1992: 131). By looking closely and questioning all the elements of outer reality, Rhoda deprives it of its authority over her. For the first time she admits that outer reality is not more real than her imaginary world, that the external world is wearing only a "semblance of life". Consequently, the inner reality, her valley "on the other side of the world" becomes more real and solid; for the first time Rhoda can fully appreciate the advantages of the safe, controllable, beautiful, and above all, unchanging space of the mind. Percival's death is a turning point in Rhoda's life as it brings a redefinition of the relation between inner and outer realities. The external world is ultimately rejected and the world of the mind embraced as her microcosm. Rhoda withdraws more thoroughly into the reality of her dreams, her loneliness deepens, she leaves Louis, and she avoids contact with other people.

Rhoda's ultimate escape from the material world takes the form of suicide, although the fact is implied rather than made clear. In her last soliloquy, she says that the monumental figure she once saw in her valley is Percival, suggesting that he became part of her imaginary landscape when he died. Death thus becomes a gate-way to a different realm, a passageway to the world of eternal beauty, order, and permanence. If Percival's death allows Rhoda to question the solidity of the material world, it also frees her desire "to be consumed", to withdraw even more completely into "the uttermost corners of the earth" (Woolf 1992: 135) by dying.

\section{Samuel Beckett's Murphy}

A similar path is at the centre of the plot in Samuel Beckett's Murphy. In comparison with The Waves and Beckett's later novels, Murphy has a more traditional form. Its plot revolves around the love story of Murphy and Celia and the pursuit of Murphy by another woman, Miss Counihan. From the very first page, however, the dynamics of the novel's action is clearly undermined by the inaction represented by the protagonist. As the novel starts, we see Murphy succumbing to his favourite activity — sitting naked, tied to a rocking chair and "setting his mind alive," separating himself from the outer world represented by distracting sights and sounds:

These were sights and sounds that he did not like. They detained him in the world to which they belonged, but not he, as he fondly hoped. (...) He sat in his chair in this way because it gave him pleasure! First it gave his body pleasure, it appeased his body. Then it set him free in his mind. For it was not until his body was appeased that he could come alive in his mind, as described in section six. And life in his mind gave him pleasure, such pleasure that pleasure was not the word. (Beckett 1993: 6)

Murphy, like Rhoda, needs to separate himself from the external, material world and to immerse himself in the inner realm. Coming alive in the mind requires silence and immobility in the outer world, as he himself says: "motion in this world depended on rest in the world outside" (Beckett 1993: 64). The body belongs to the external realm and thus to fully appreciate the life in the mind, Murphy needs to distance himself from the physical and the bodily. The inner realm is associated with peace, security, pleasure and a sense of freedom, the external world with the pressures of communal living.

The tension between the mind and the body, between inner and outer realms, is the key opposition and the structuring theme of the novel. For Murphy, like for Rhoda, the 
most fundamental experience of being in the world is rooted in an essential split into the body and the mind: "Murphy felt himself split in two, a body and a mind. They had intercourse apparently, otherwise he could not have known that they had anything in common" (Beckett 1993: 64). The separation, with typically Beckettian humour, is explained in terms of the experience of a kick: "[ $\mathrm{t}]$ he mental experience was cut off from the physical experience (...). He neither thought a kick because he felt one nor felt a kick because he thought one" (Beckett 1993: 64). The split, as numerous critics pointed out, evokes Cartesian ruminations on the relation between the material and the mental. In contrast to Descartes, however, Murphy favours a complete separation of res cogitans from res extensa. The mind seems to him "bodytight" (Beckett 1993: 64) and while he accepts that the intercourse between the two is somehow effected, the actual channel that links the body to the mind remains a mystery and one that is "of little interest" to the protagonist.

In the notorious Section Six, announced at the beginning of the novel, the narrator ventures to explain the meaning of the expression "Murphy's mind" as "it felt and pictured itself" to Murphy (Beckett 1993: 63). As C. J. Ackerley explains, trying to define where Beckett's ideas in this section come from would be "an extravagance and impertinence (...) The chapter, brief as it is, represents a compression and distillation of his years of reading, from the pre-Socratics through the traditions of Western mysticism and reason to recent discoveries of psychology" (Ackerley 2010: 117). The section has been interpreted varyingly, as a parody of the Cartesian self-contained thinking subject, the Leibnizean ideal of splendid self-adequacy (Kearney 1988: 66-67), and the Neoplatonic realm of the immutable and the timeless (Steinberg 1972: 105). The chapter "moves from Cartesian clarity to Schopenhauer's will-lessness, by means of Spinoza's Ethics, Leibniz's Monadology, Geulincx's Ethica, and Kant's Critique of Pure Reason" (Ackerley and Gontarski 2004: 388). What interests us here, however, is the way the section develops the idea of the mind as a place, a "mental chamber" from which there is "no way out":

Murphy's mind pictured itself as a large hollow sphere, hermetically closed to the universe without. (...) He was split, one part of him never left the mental chamber that pictured itself as a sphere full of light coming into dark, because there was no way out. (...) There were the three zones, light, half light, dark, each with its speciality.

In the first one were the forms with parallel, a radiant abstract of the dog's life, the elements of physical experience available for a new arrangement. (...) In the second were forms without parallel. Here the pleasure was contemplation. (...) In both these zones of his private world Murphy felt sovereign and free, in the one to requite himself, in the other to move as he pleased from the unparalleled beatitude to another. There was no rival initiative.

The third, the dark, was a flux of forms, a perpetual coming together and falling asunder of forms. (...) Here he was not free, but a mote in the dark of absolute freedom. He did not move, he was a point in the ceaseless unconditioned generation and passing away of line. (...) a missile without provenance or target, caught up in a tumult of non-Newtonian motion. So pleasant that pleasant was not the word. (Beckett 1993: 63-66)

In this extended passage, parodying scientific and philosophical language, the narrator tries to capture Murphy's sense of "what he kept on calling, indefatigably, the little world" (Beckett 1993: 103). For Murphy, like for Rhoda, the mind does not "feel" like a flow of thoughts. It feels like a space. As Murphy says, "what he called his mind functioned not as an instrument but as a place" (Beckett 1993: 101), as a "mental chamber" in which, under 
certain circumstances, after shutting out the outer world, one can hide. He pictures it as a separate universe, a self-contained, multidimensional sphere with its own rules and logic. As in The Waves, setting the mind alive does not mean thinking, it means being in a separate world, "mov[ing] among its treasures" (Beckett 1993: 111). Yet, while in Woolf's novel the mind is conceived of as a set of recurrent landscapes, united by water imagery, in Murphy its presentation is less symbolic and visual and more discursive and rationalized. While Woolf's method is poetic, drawing on the mythical symbolism of the four elements, Beckett's is theoretical and intellectual.

The philosophical inspirations behind the tripartite division of Murphy's mind are vast, as Ackerley duly demonstrates. They range from Greek idealism, through Christian mystical tradition to Cartesian rationalism (Ackerley 2010:117-125). Yet perhaps its most clear resonance is with the conceptualization of the human psyche formulated on the grounds of psychoanalysis, most specifically with Freudian topologies of the self, visualizing the mind in terms of three realms, each with a different type of experience, different speciality and a different relation to the outer world. The three zones of Murphy's mind corresponding to the "topographical agencies of the unconscious, preconscious and conscious" (Keitel 1989: 29) are represented in spatial terms, as different regions. The relations between the different parts of the mind are defined in terms of spatial coordinates: "The mind felt its actual part to be above and bright, its virtual beneath and fading into dark (...). The third, the dark, was a flux of forms, a perpetual coming together and falling asunder of forms" (Beckett 1993: 64). The pleasure of the darkest realm results from "the sensation of being a missile without provenance or target, caught up in a tumult of non-Newtonian motion" (Beckett 1993: 66).

Psychoanalytical resonances in Beckett's fiction have been analysed by numerous critics and the impact of Beckett's own therapy and his reading in the field has also been discussed quite extensively (see, e.g. Ackerley, Murphy, O’Hara). Ackerley and Gontarski explain that the vision of the mind in Murphy might have been inspired by Jung's lecture that Beckett attended at the Tavistock Clinic, during which Jung "presented a diagram showing the different spheres of the mind and the dark centre of the unconscious". They conclude, referring to Knowlson, that "if Murphy could not have gone into the dark zone without SB's descent into the depths with Bion, equally it could not have been pictured without the aid of Jung and Freud" (Ackerley and Gontarski 2004: 389).

As in the case of Rhoda, Murphy's encounter with external reality is only brief and ultimately makes him withdraw even more completely into his inner world. When he gets a position as a male nurse in a mental asylum, he leaves Celia and returns to the habit of rocking in a chair and setting his mind alive. At this point both subplots fail: his love affair is abruptly interrupted and he is not found by Miss Counihan. Murphy, the pivot for the novel's plot, ultimately rejects his role as a storymaker and the decision may be seen as analogous to Rhoda's epiphany after Percival's death. They are moments of the characters' assertion of the internal over the external, of the reality of the mind over that of the body. The two protagonists identify more fully with what they see as their true, inner self over the false, external identity. They reject the shared reality and withdraw from the world of "big blooming buzzing confusion" to "what he kept on calling, indefatigably, the little world" (Beckett 1993: 4, 103). 
In both novels, the assertion of the inner over the outer realm leads characters to death; in both there is a suggestion of suicide. While in The Waves Rhoda's suicide is suggested by the poetic imagery inscribed in her landscapes, in Murphy it is presented as a rational effect of the changing definition of the real that Murphy formulates while working in the mental asylum:

The definition of outer reality, or of reality short and simple, varied according to the sensibility of the definer. But all seemed agreed that contact with it, even the layman's muzzy contact, was a rare privilege. On this basis the patients were described as "cut off" from reality [and] the function of treatment was to bridge the gulf, translate the sufferer from his own pernicious little private dunheap to the glorious world of discrete particles, where it would be his inestimable prerogative once again to wonder, love, hate, desire, rejoice and howl in a reasonable balanced manner (...) All this was duly revolting to Murphy, whose experience as a physical and rational being obliged him to call sanctuary what the psychiatrists called exile and to think of the patients not as banished from the system of benefits but as escaped from a colossal fiasco. The issue therefore (...) lay between nothing less fundamental than the big world and the little world, decided by the patients in favour of the latter, revived by the psychiatrists on behalf of the former, in his own case unresolved. (Beckett 1993: 101)

To Murphy, the world without does not appear as a safe sanctuary with an enticing system of benefits, as the psychiatrists would like him to see it, but as a colossal fiasco of unstable discrete particles and turbulent emotions. Raising Lazarus from the dead, he remarks sarcastically, seems to be "the one occasion on which the Messiah had overstepped the mark" (Beckett 1993: 102) and death is not defined in negative terms but as a positive state of "not being."

\section{Conclusion}

The similarities in the plots of Rhoda and Murphy, centred on the changing relationships between the characters' inner and outer realities, point to a more general congruence between the interests of the two writers that constitute an important heritage of the genre of the modernist psychological novel. Though in different ways, Woolf and Beckett both trod on ground that psychology was at the time only beginning to explore. The schizoid condition, which, as R. D. Laing was later to explain, consists in "developing a microcosm within [one]self" without recourse to the outer world of persons and things and which involves "a persistent scission between the self and the body" (Laing 1965: 74, 78) finds two of its earliest literary representations in The Waves and Murphy. Woolf's poetic and highly symbolic landscapes and Beckett's intellectual, comic ruminations capture the experience of the unembodied self haunted by a sense of "ontological insecurity" (Laing 1965: 39). They represent important attempts at portraying "the experience rather than appearance of madness" (Valentine 2003: 101) by reconstructing "the patient's way of being himself in his world" that Laing's existential psychiatry was calling for years later.

But the two novels also represent important voices in the process of interiorization and spatialization of the mind that took place in modernist fiction. In contrast to the "time-novels" that portrayed the mind as a flow of thoughts, Woolf and Beckett imagined it as a place, a spatially extensive realm that could be creatively explored by the different aspects of the self. The representation of the schizoid condition, with its radical redefinition of the ontological relationship between inner and outer realities, offered the writers 
an opportunity to construct extended visions of inner worlds. The mind became a separate universe, a fully developed world of its own, imagined in cosmological terms and experienced as a kind of physical space, a mental locality that offered an alternative sense of reality to the world without.

\section{Bibliography}

Ackerley Chris J. (2010), Demented Particulars: The Annotated "Murphy”, Edinburgh UP, Edinburgh.

Ackerley Chris J., Gontarski Stanley E. (2004), The Grove Companion to Samuel Beckett: A Reader's Guide to His Works, Life, and Thought, Grove Press, New York.

Beckett Samuel (1993), Murphy, Calder, London.

Brown Dennis (1989), The Modernist Self in the Twentieth-Century English Literature, St. Martin's Press, New York.

Cohn Dorrit (1978), Transparent Minds: Narrative Modes for Presenting Consciousness in Fiction, Princeton UP, Princeton.

Dion Nicholas (2012), Spacing Freud: Space and Place in Psychoanalytic Theory, PhD Thesis, University of Toronto, Toronto.

Edel Leon (1964), The Modern Psychological Novel, Grosset and Dunlap, New York.

Frank Joseph (1991), The Idea of Spatial Form, Rutgers UP, New Brunswick.

Humphrey Robert (1954), Stream of Consciousness in the Modern Novel, University of California Press, Berkeley.

Kearney Richard (1988), Transitions: Narratives in Modern Irish Culture, Manchester UP, Manchester.

Keitel Evelyne (1989), Reading Psychosis: Readers, Texts and Psychoanalysis, Basil Blackwell, Oxford.

Kern Stephen (1983), The Culture of Time and Space 1880-1918, Harvard UP, Cambridge, Mass.

Laing Ronald D. (1965), The Divided Self: An Existential Study in Sanity and Madness, Penguin, Baltimore.

Murphy Emily Christina (2014), Beckett's Everyday Psychopathology: Reading Male Nervous Hysteria in "Murphy", "ESC" 40.1 (March).

O'Hara James (1997), Samuel Beckett's Hidden Drives: Structural Uses of Depth Psychology, University Press of Florida, Florida.

Quinones Ricardo J. (1985), Mapping Literary Modernism: Time and Development, Princeton UP, Princeton.

Sass Louis A. (1992), Madness and Modernism: Insanity in the Light of Modern Art, Literature and Thought, Harvard UP, Cambridge. 
Sinclair May (1982), Mary Olivier: A Life, Dial Press, New York.

Steinberg S.C. (1972), The External and Internal in "Murphy", "Twentieth Century Literature", 18.2 (April).

Stevenson Randall (1992), Modernist Fiction: An Introduction, Harvester, Wheatsheaf, New York. Sypher Wylie (1962), Loss of the Self in Modern Literature and Art, Random, New York.

Terentowicz-Fotyga Urszula (2006), Semiotyka przestrzeni kobiecych w powieściach Virginii Woolf, Wydawnictwo UMCS, Lublin.

Terentowicz Urszula (1995), The World and the Word in The Waves by Virginia Woolf, "Lubelskie Materiały Neofilologiczne", nr 19.

- (1996), Triptych of Non-Verbal Search for Reality. The Female Mind in The Waves by Virginia Woolf [in:] Approaches to Fiction, ed. L. Kolek, Wydawnictwo Forum, Lublin.

Valentine, Kylie (2003), Psychoanalysis, Psychiatry and Modernist Literature, Palgrave, Houndmills. Woolf Virginia (1925), Modern Fiction [in:] The Common Reader: First Series, Harcourt Brace Jovanovich, New York.

— (1992), The Waves, Oxford UP, Oxford. 